\title{
EENE OVERLANDREIS
}

\author{
vIT \\ I N D I H N A A R NEDERL A N D,
}

IN

$1674-1675$.

Onder de merkwaardigste zaken, die er in deze eeuw reeds tot stand kwamen, behoort ongetwijfeld de versnelde en geregelde gemeenschap van en naar Indië. Iedere natie toch, die met die gewesten in betrekking staat, heeft daarbij een overwegend belang. De voordeelen, die uit den nieuwen staat van zaken voor ieder voortspruit, zullen we wel niet uit een behoeven te zetten; ze springen te duidelijk in het oog ${ }^{1}$. Hoewel de zoogenaamde overlandreizen in vroegere eeuwen niet vreemd waren, behoorden ze echter tot de zeldzame gebeurtenissen en werden die althans niet spoedshalve gedaan.

De weg, dien men uit Indië daartoe gewoon was te nemen, verschilde dan ook aanmerkelijk met dien men tegenwoordig daartoe gebruikt. Nemen we bij voorbeeld het eiland Ceilon voor het punt van vertrek uit Indië aan, dan zien we de reizigers zich eerst naar Persië begeven, hetzij dan naar Gamron of Ormuz - beide aan den mond der Persische golf gelegen van waar ze langs den waterweg door de genoemde golf of wel over land naar Bassora kwamen. Van Bassora moesten ze door de woestijn - dat wel de kortste, maar ook tevens de gevaarlijkste weg was - of wel over Bagdad en Mousol naar Aleppo en Alexandrette, waar ze scheepsgelegenheid moesten afwachten, ten einde naar Europa te kunnen oversteken. Gewoonlijk begaven ze zich naar Livorno of Venetiën, om dan de reis door Italië en Duitschiand ten einde te brengen.

Zoodanige reizen waren gevaarlijk, vermoeijend en langdu-

1 Van welk gewigt deze weg reeds voor Engeland is geweest, bij het zenden van troepen naar de Krim en later tijdens den opstand in Britsch. Indië, is genoeg bekend. 
rig. De woestijn was - wanneer men niet met eene sterke karavaan reisde - gevaarlijk door te trekken van wege de menigte roofgierige Arabieren, die op den vreedzamen reiziger loerden, ten einde hem of geheel uit te plunderen, of wel hem een belangrijk hoofdgeld lieten betalen voor het voortzetten zijner reis.

De reis was in de tweede plaats vermoeijend, daar men al datgeen miste, wat ons thans het reizen aangenaam maakt, en eindelijk langdurig, daar de reis door Persië tot Aleppo soms drie maanden duurde. Soms lagen er te Alexandrette geene schepen zeilree, zoodat men daar weder een geruimen tijd kon doorbrengen, en, kwam men eindelijk in eene Europesche haven, dan kon men daar nog tot 90 dagen quarantaine houden; terwijl de reisgelegenheden in Europa, tot in de vorige eeuw, ook nog veel te wenschen overlieten.

Vertrekt men daarentegen thans van Ceilon, een gemakkelijk stoomschip brengt den reiziger in 16 à 17 dagen te Suez, waar hij zich spoedig op een spoortrein over Kä̈ro naar Alexandrië zal kunnen begeven en daar in een paar dagen aankomen. In laatstgenoemde plaats heeft hij slechts te kiezen, werwaarts hij zijn reis wil voortzetten, hetzij over Triëst, Marseille of Southampton; stoomschepen en spoorwegen staan hem overal ten dienst, zoodat de overlandreizen uit Indië in den tegenwoordigen tijd niet meer met de vroegeren kunnen worden vergeleken (1). De eerste, die in de $16^{\text {de }}$ eeuw de reis over land, langs een' weg nog nooit te voren bereisd, ondernomen heeft, was de Portugees Antonio 'l'enreiro, die op order van den kapitein der vesting van Ormuz, Christoforo di Mendoza, van daar de reis overland naar Portugal aannam, om aldaar de tijding over te brengen van den oorlog met Soliman, Koning der Turken. Hij vertrok van Ormuz in 1528 naar Bassora, van daar doortrok hij de woestijn op drommedarissen; met een Moor tot leidsman, en niet zonder groot gevaar voor roovers en wild gedierte, die aldaar in menigte waren. Hij besteedde 22 dagen tot het doortrekken der woestijn en kwam tot aan Cocana en van daar in Aleppo; van hier zette hij zijne reis voort naar Tripolie di Soria (Syrië?), stak van daar naar Cyprus over en kwam over Italië in Portugal, alwaar de Koning Joao hem eene goede belooning schonk voor den nieuwen en met vele gevaren gepaard geweest zijnden togt. Het daarvan door hem

1 Aanteekeningen 1. 
opgestelde verhaal, onder den titel van wegwijzer, werd in 1556 te Coimbra gedrukt '.

Hoewel wij reeds van het begin der $17^{\text {de }}$ eeuw vasten voet in Indië hebben bekomen, blijkt het echter niet uit de archiven, dat onze Hollanders veel van dezen weg gebruik hebben gemakt, met uitzondering echter van het verzenden hunner brieven, die steeds over Aleppo werden verzonden. De eerste, die het voornemen had deze reis van Batavia te ondernemen, was waarschijnlijk de Opper-koopman Hendrick Bruijstens, aan wien op zijn daartoe aan de Hooge Regering gedaan verzoek, op den 4den Januarij 1620, de vergunning verleend werd, met een Compe. schip naar de kust van Coromandel overgevoerd te worden, om van daar voorts de reis over land naar het Vaderland te doen "op eijgen koste, last en perijckel."

Bij resolutie van den $15^{\text {den }}$ daaraanvolgende, worden de voorwaarden vastgesteld, waarnaar ze zich zouden hebben te gedragen; zijnde inmiddels ook aan den vrịburger Jan Hendrikz Sael toegestaan, zich met Braijstens op reis te begeven.

Het schijnt echter, dat deze reis als toen geen voortgang gehad heeft, daar beide personen in dat en het volgende jaar zich nog op Batavia bevonden?

De Gouverneur van Amboina, Herman van Speult, deed in 1623 daartoe mede aanzoek aan de Hooge Regering te Batavia, die dit verzoek aan de beslissing der vergadering van Zeventienen onderwierp; dan deze waren hiertoe niet genegen. Bij hunne resolutie van den 23sten October 1623, bepaalden zij onder meer anderen het volgende: “Over het versoek van den “Gouverneur van Amboina, Herman van Speult, om over de “custe van Cormandel, Suratte, Persië en Sijrië, te lande te "huis te mogen comen, met beleeffde brieven naer Indië te "schrijven, dat het niet wordt geconsenteert, ende dat (men) “oock't selve aen niemant sal toestaen, sonder expres consent "van de zeventiene."

Dewijl de Bewindhebberen nu zoo stellig verklaarden, dat de reizen over land uit Indië niet zonder daartoe de bijzondere vergunning van hen te hebben bekomen, mogten gedaan worden, mag men wel aannemen, dat die niet dan in enkele gevallen zal verleend zijn geworden.

1 Indisch Archif 1849, I Deel, bl. 341.

2 Tijdschrift voor Indische Taal- Land- en Volkenkunde. Batavia 1855, Deel IV. Nienwe Serie Deel I, bl. 281. 
De gebeurtenissen, die er op het eiland Ceilon en de vaste Kust van Indië in de jaren 1672 en 1673 hadden plaats gehad en nog voortduurden, waren dan ook wel van dat gewigt, dat Rijckloff van Goens, Super-Intendent en Admiraal over het eiland Ceilon, de kusten van Coromandel, Malabaar, Madure, enz. op eigen gezag kon goedvinden, zijn' Secretaris, den Onder-Koopman Joannes Leeuwenson, te gelasten, het verslag dier belangrijke gebeurtenissen in persoon aan de Bewindheb. beren ter vergadering van de Zeventienen in Amsterdam over te brengen.

In deze jaren toch had de roemzuchtige Koning van Frankrijk, Lodewijk XIV, het er op toegelegd, de kracht van Nederland ook in Oost-Indië te verlammen. Eene vloot onder het bevel van den Admiraal de la Haye Ventelay, en bijgestaan door François Caron, - een Hollander, die door gekrenkte eerzucht verleid, van zich kon verkrijgen, der Comp., waaraan hij alles verpligt was, onder de vlag van den vijand van zijn vaderland alle mogelijke nadeelen te berokkenen - zouden hiertoe dienstig wezen. Maar dank zij de wakkerheid en het beleid van den dapperen van Goens, die het gevaar, waaraan Ceilon en de Indische kust was blootgesteld, niet alleen wist af te wenden, maar en de Franschen en de Engelschen, - die zich aldaar mede bij hen hadden aangesloten - zoodanige slagen toe te brengen, dat ze hun heil in de vlugt moesten zoeken '.

Met het overbrengen der "importante papieren," op deze gebeurtenissen betrekking hebbende, werd, zoo als wij hier voren zeiden, de Onder-Koopman Leeuwenson belast; en het is het dagregister dier reize, dat wij het genoegen hebben de lezers dezer Bijdragen aan te bieden. Men zal er bij het lezen uit ontwaren, dat wat wij op de voorgaande bladzijde aanvoerden over het gevaarvolle, vermoeijende en langdurige der reizen in die dagen, ook ten volle van toepassing op deze reis is geweest.

De Schrijver van het artikel in het Tijdschrift voor Indische Taal- Land- en Volkenkunde, op de vorige bladzijde aangehaald, zegt aan het einde er van “Eenig gedrukt relaas van zoodanige "reis uit dien tijd is mij nimmer voorgekomen."

Niettegenstaande wij ons daartoe mede nog al eenige moeite

I Verhandelingen en Berigten betrekkelijk het Zeewezen, enz. 1856, Afd. 4, No. 2. Het gevecht tegen de Engelschen in Oost-Indië, op den $1^{\text {sten }}$ September 1673, door den Commandeur Cornelis van Quaelbergen. 
hebben gegeven, mogt het ook ons niet onder de oogen komen; zoodat men met eenigen grond van waarschijnlijkheid zal mogen aannemen, dat dergelijke relazen van Nederlandsche reizigers uit dien tijd, zoo ze al bestaan hebben, niet veel meer voorkomen ${ }^{1}$; zelfs in handschrift behooren ze tot de zeldzaamheden, zijnde dit voor als nog het eenige, wat ons voor als nog uit de papieren der voormalige Oost-Indische Compagnie bekend is.

LEUPE.

1 In den Catalogus der Tentoonstelling van voor Nederland belangrijke Oudheden en Merkwaardigheden in de Stad en Provincie Utrecht voorhanden enz. 1857 komt onder XII, N0. 120, voor "Eene beschrijvinge "van de Lantrijs in Europa en Asia gedaan door den Heer Carel Quina, Ridder, Begonnen in 't jaar 1668 en volbragt in 't jaar 1667 (Sic.) Handschrift groot 153 bladen in fol. enz. Daar mij dit HS. niet bekend is, kan ik niet opgeven of dit eene overlandreis uit Europa naar Indië is geweest. 